\title{
SPLITSKE ADRESE VLADANA DESNICE
}

\section{Drago Roksandić i Ivana Cvijović Javorina}

UDK: 929Desnica, V.:728.1(497.5 Split)“1920/45“(083.824)s

Stručni članak

Sažetak: Tekst je fragment izložbe Vladan Desnica i Desničini susreti održane u Sveučilišnoj knjižnici u Splitu od 20. rujna do 6. listopada 2014., a potom u Gradskoj knjižnici „Juraj Šižgorić“ Šibenik od 28. veljače do 11. ožujka 2015. Autori izložbe su prof. dr. sc. Drago Roksandić i Ivana Cvijović Javorina. Izdvojena cjelina daje kratak pregled adresa na kojima je Desnica živio tijekom svog dvadesetogodišnjeg boravka u Splitu.

Ključne riječi: izložba, Vladan Desnica, Split

0 d 1920. do 1945. godine, tj. od petnaeste do četrdesete godine svog života Vladan Desnica je bio Splićanin. Imajući na umu da je gimnazijsko obrazovanje stekao na ratnoporatnim razmeđima u Zadru, Splitu i Šibeniku, a pravničku sveučilišnu izobrazbu u Zagrebu te da je koncem 1920-ih godinu dana proveo u Parizu, vraćajući se uvijek iznova roditeljima u Split, ali i brinući s njima za posjede u Obrovcu i Islamu Grčkom, ne bi se ipak moglo reći da je bio baš „fetivi“ Splićanin. Međutim, za razliku od 1920-ih godina, tridesete su godine dvadesetog stoljeća bile vrijeme njegova egzistencijalnog smirivanja u Splitu. Koliko god osjećao otpor prema pravničkoj karijeri, alternative nije imao. Bila je dovoljno unosna da se mogao odlučiti na ženidbu s Ksenijom Carić i podizanje obitelji. U svega nekoliko godina braka dobio je troje djece. Svoju je budućnost očito vidio u tom gradu, naročito nakon što su i on i njegov otac poslije mnogo godina provedenih u unajmljenim stanovima u Splitu najvjerojatnije 1938. uselili u prostranu vlastitu kuću na Tomića stinama 1. Međutim, Travanjski rat 1941. i očeva smrt u srpnju 1941. godine suočili su ga s neizbježnošću mnogobrojnih izbora koji su ga postupno vodili sve dalje i dalje od Splita. Ipak, Split je sve intenzivnije prelazio u sfere njegove artističke imaginacije pa su splitske godine, adrese i situacije u njegovu životu ključne za razumijevanje onog Vladana Desnice koji nas najviše zanima - pisca Vladana Desnice.

Vladan Desnica je - što s roditeljima, što sa suprugom i djecom, što poslovno - živio u Splitu na sljedećim adresama: Hotel „Bellevue“ (1920.), Sinjska 7 (192?. - 1934.), Bihaćka 7 (1934. - 1938.), Bihaćka 5/II. (1938.), Tomića stine 1 (1938. - 1945.). Kronologija je uvjetna jer privatna dokumentacija nije dovoljno istražena, drugi arhivski izvori još manje, a obiteljsko pamćenje - prema izjavama samih članova obitelji - nije dovoljno pouzdano.

U osobnoj ostavštini Vladana Desnice malo je sačuvanih pisama iz tog razdoblja s omotnicama. Sačuvane omotnice su donekle pouzdan vodič po njegovim splitskim adre- 
sama, ali ipak nedovoljno. Više je omotnica na kojima piše „Gospodin Vladan Desnica, Split“. Činjenica da je ta pisma dobio svjedoči o tome da Split u to doba, koliko god bio grad u usponu, još uvijek nije bio uistinu velik grad, grad u kome se ne bi znalo „tko je tko" te da je prezime Desnica u Splitu tada bilo prepoznatljivo. Takvim ga je prije svega činio njegov otac Uroš Desnica, ali je i Vladan Desnica vremenom očito bivao sve poznatiji. $U$ tom je smislu zanimljiv manje-više nasumičan izbor sačuvanih adresa s naznakom pošiljatelja:

Gosp[odin] / Vladan Desnica / Dra Uroša Desnice / Split

(Vladimir Desnica, Obrovac, 18. listopada 1920.)

P[oštova]n[i] gospodin / Vladan Desnica / „Hotel Bellevue“ / Split / Dalmacija (Mate Gjidera, Zagreb, 25. listopada 1920.)

Mladi gospodin Vladan Desnica / Dra Uroša Desnice Učenik V. gimnaz[ijskog] razreda / Split

(Vladimir Desnica, Obrovac, 25. siječnja 1921.)

Štovani Gospodin / Vladan Desnica / iurist / Split / Kod gimnazije

(Olinko Delorko, Zagreb, listopad 1931.

Vladan U. Desnica / Split / Vrhmanuška 20

(Desničin pečat, 1934.)

Gosp[odin] Dr Vladan Desnica / Bihaćka 7 / Split / Jugoslavija

(G. Gesemann, Prag-Dejvice 446, 14. studenoga 1935.)

Gospodin / Vladan Desnica / Sinjska ul. 7

(Ignjat Job, Umjetnički salon Galić, Split, lipanj 1935.)

Monsieur / Vladan Desnica / Split / Yougoslavie

(Bogdan Radica, Genève, 17. rujna 1938.)

Naklada Kadmos / Split / Bihaćka ul. 5/II

(Matica srpska, Novi Sad, 1. ožujka 1938.)

Presudno je bilo očevo kretanje u službi i odvjetničkoj karijeri 1920-ih godina. Otac je napustio svoj zadarski odvjetnički ured, a cijela obitelj Zadar pod ponižavajućim uvjetima u vrijeme talijanske okupacije grada. Sačuvani su ključni dokumenti o tom razdoblju, a dostupno je i javno svjedočanstvo: 
Oglas. Donosim do javnog znanja da sam ustupio svoju advokatsku kancelariju u Zadru gosp. D.ru Vjekoslavu Salvi, Advokatu u Zadru, kome sam ujedno ustupio i svoj arhiv te svoje tražbine. Pozivljem zato G.G. klijente da se toliko za nastavak posala, koliko za isplatu računa i sve ostale poslove, koji su u vezi sa mojim bivšim poslovodstvom, obrate na D.r Vjekoslav Salvi. Zadar, 26 juna 1920. D.r Uroš Desnica ${ }^{1}$

Odvjetnički poslovi preneseni su u Obrovac, gdje ih je do 1927. godine dijelio s bratom Boškom, također bečkim pravnikom, a politička djelatnost odvela ga je s obitelji u Split. Uroš Desnica držao je svoj Odvjetnički ured u Obrovcu sve do 9. srpnja 1927. godine iako je u Splitu bio namješten već od 1920. godine. ${ }^{2}$ U Odvjetničku komoru u Splitu bio je upisan 26. kolovoza 1927. godine. ${ }^{3}$ Što je Uroš Desnica radio u Splitu 1920./1921. godine mnogima je nepoznanica. Sačuvana osobna dokumentacija olakšava orijentaciju. U njegovoj molbi Predsjedništvu Ministarskog savjeta u Beogradu iz listopada 1940. godine u vezi s reguliranjem prava na mirovinu Uroš Desnica naveo je sljedeće:

Ukazom od 2/IX. 1920 naimenovan za poverenika za unutrašnje poslove i zamenika Pretsednika Vlade. Skoro za tim preuređene su pokrajinske vlade i naimenovani Namesnici za Hrvatsku, Sloveniju i Bosnu, dok za Dalmaciju nije bio naimenovan Namesnik već sam ja [Uroš Desnica - nap. aut.] ostao kao vršioc dužnosti namesnika sve do 31 avgusta 1921. U stvari ja sam tu dužnost vršio sve do oktobra 1921. g., jer je imenovani pokr[ajinski] Namesnik dr Stevan Metličić nije od mene preuzeo nego tek (...) 1921. god[ine]. ${ }^{4}$

Kada je o Urošu Desnici riječ, može se pretpostaviti da je živio u Sinjskoj 7, gdje je imao i odvjetnički ured, čini se od 1927. do 1938. godine. Još je uvijek, naime, otvoreno pitanje kada je obitelj Desnica konačno preselila u vlastitu kuću na Tomića stinama 1, ali vjerojatno ne prije 1938. godine. U prepisci Vladana Desnice sačuvano je nečitko potpisano pismo jednoga njegovog splitskog „vršnjaka“ od 3. ožujka 1938. godine, koji mu se javio zahvaljujući na poklonjenim Croceovim Esejima iz estetike:

Dragi Vladane,

Nameravao sam da pročitam, pa da ti, blagodareći, izrazim i svoje utiske. Međutim, nisu Eseji još stigli na stol (jer moram da dovršim Huxley-a) pa ti kažem, ne dangubeći, hvala na pažnji i lepom poklonu. Po rukopisu možeš da vidiš koliko sam „u priši“ zbog nekih akata, običnih i dosadnih ali hitnih. Nadam se da ste svi zdravi i veseli i da ste se savršeno snašli u novoj ulozi splitskih kućevlasnika. Mojoj staroj reci da si primio ove retke, te ima mesta verovanju da sam živ. Sve vas najsrdačnije pozdravlja, u mnogo čemu zavidi i iskreno voli tvoj vršnjak $(. . .)^{5}$

1 Objavitelj Dalmatinski. Zvanični list Guvernerstva Dalmacije te Dalmatinskog i Korčulanskog Otočja (Zadar), br. 28, 10. 7. 1920., 1.

2 Službeni glasnik. Zvanični list Splitske i Dubrovačke oblasti (Split), br. 33, 3. 5. 1927., 1.

3 Službeni glasnik. Zvanični list Splitske i Dubrovačke oblasti (Split), br. 66, 2. 9. 1927., 1.

4 Osobna ostavština Vladana Desnice. Sačuvan je i odgovor iz Ministarstva unutrašnjih poslova od 16 . studenoga 1940. godine: „Iz uverenja Ispostave Banske vlasti u Splitu I br. 6330/40 od 9 oktobra 1940. god. vidi se pak, da je molilac kao poverenik za unutrašnje poslove i zamenik Pretsednika Pokrajinske vlade u Dalmaciji, podneo ostavku na službu, koja mu je uvažena ukazom od 21 jula 1921 god. D. Br. 1432/21. Uvaženjem ostavke na službu službenik gubi sva prava, koja je dotle kao takav imao. Ako je i pravo na penziju stekao i to pravo gubi službenik, kome služba prestane uvaženjem ostavke.“

5 Osobna ostavština Vladana Desnice. 
U svome splitskom domu Vladan Desnica je ostao najkasnije do ljeta 1942. godine, kada je kao pristav okupacijskog Državnog tužiteljstva bio premješten na mjesto prevoditelja u Zadar. Namještenje u Zadru omogućavalo mu je manje-više stalni kontakt s posjedom u Islamu Grčkom, koji je nakon proljeća 1941. godine praktično ostao napušten. Bilo je to i egzistencijalno pitanje za Desničinu obitelj jer se u Splitu pa i Zadru sve više gladovalo, a Vladan je tada brinuo o svojoj supruzi, troje malodobne djece, majci i sestri. Nitko od njih nije imao nikakvih prihoda.

Veliki je problem bio kako sačuvati kuću u Splitu. Rođaci sa suprugine strane i prijatelji u Splitu učinili su uistinu sve što su mogli da zaštite što više imovine. Najveći dio sačuvanog je na koncu ipak propao, pogotovo nakon jeziva savezničkog bombardiranja Splita 3. lipnja 1944. godine, tijekom kojeg je bila pogođena i kuća obitelji Desnica.

Obitelj Vladana Desnice živjela je u unajmljenom stanu u Zadru (Via Guglielmo Marconi, k. br. 8) kada su započela uzastopna saveznička bombardiranja grada u jesen 1943. godine. Sve im je propalo što su u taj stan bili prenijeli iz Splita. Nije im ostalo ništa drugo nego otići na vlastiti posjed u Islam, gdje su se bar lakše mogli prehranjivati, ali i gdje im je opstanak nerijetko bio još i neizvjesniji na „poluoslobođenom teritoriju“. (Desničin roman Zimsko ljetovanje u biti je literarna reinterpretacija zadarskih i islamskih osobnih iskustava u to doba.) Njemačka vojska, obaviještena početkom 1944. godine da je u Kuli Stojana Jankovića smještena jedna partizanska jedinica, uputila je zrakoplov koji je bombardirao Kulu 23. siječnja. Izginula je veća skupina partizana, navodno njih dvadesetak, iako njihova imena nikada nisu egzaktno identificirana. Tom su prilikom dijelovi Kule teže oštećeni. ${ }^{6}$ Nitko od obitelji Desnica ni tom prilikom nije stradao, ako se ne računaju psihički učinci.

Nakon konačnog odlaska u partizane (u srpnju 1944. godine od Islama Grčkog preko Barija do Zagreba u svibnju 1945. godine) Vladan Desnica nikada se više nije vratio živjeti u Split. Redovito je dolazio, uglavnom na proputovanjima za Jelsu, gdje je živjela Ksenijina rodbina. Tada bi se nalazio s ljudima - poput Vladimira Rismonda - s kojima je od rane mladosti dijelio životna iskustva. Od 1945. do svoje smrti 1967. godine živio je u Zagrebu. Pokopan je u obiteljskoj crkvici sv. Đurđa u Islamu Grčkom.

6 Usp. Državni arhiv u Zadru - Kotarska komisija za ratne štete Benkovac - mjesto: Islam Grčki, br. 73 od 19. rujna 1945. 


\section{$\cos$}

\section{The Addresses of Vladan Desnica in Split}

The paper is a fragment of the exhibition Vladan Desnica and Desnica's encounters held in the University Library of Split from 20 September to 6 October 2014, and then in the Municipal Library "Juraj Šižgorić" in Šibenik from 28 February to 11 March 2015. The authors of the exhibition were prof. dr. Drago Roksandić and Ivana Cvijović Javorina. One particular section gave a short list of addresses at which Desnica lived during his twenty years of living in Split.

Keywords: exhibition, Vladan Desnica, Split 1920-1945 


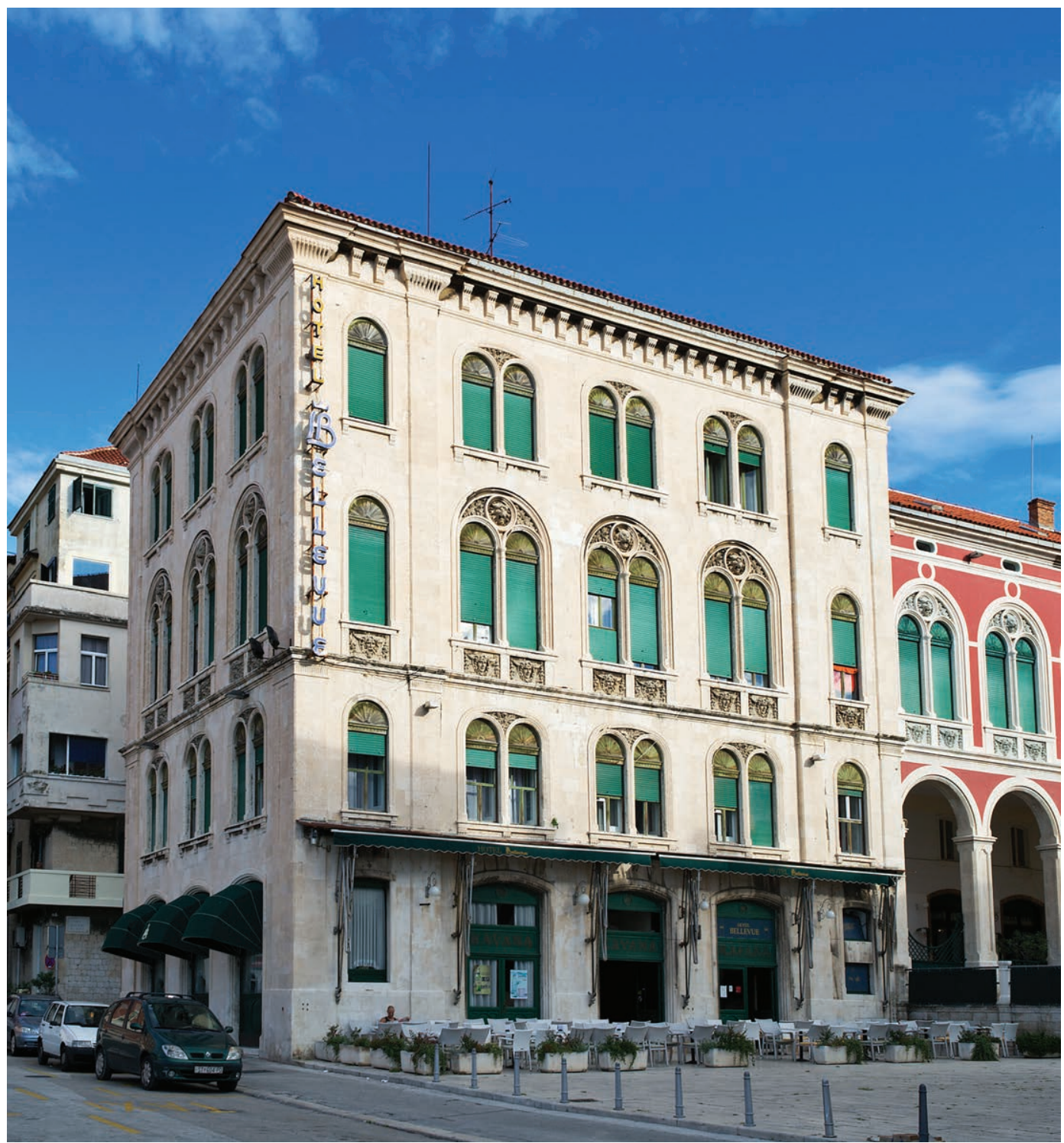

Sl. 1. Hotel „Bellevue“ 


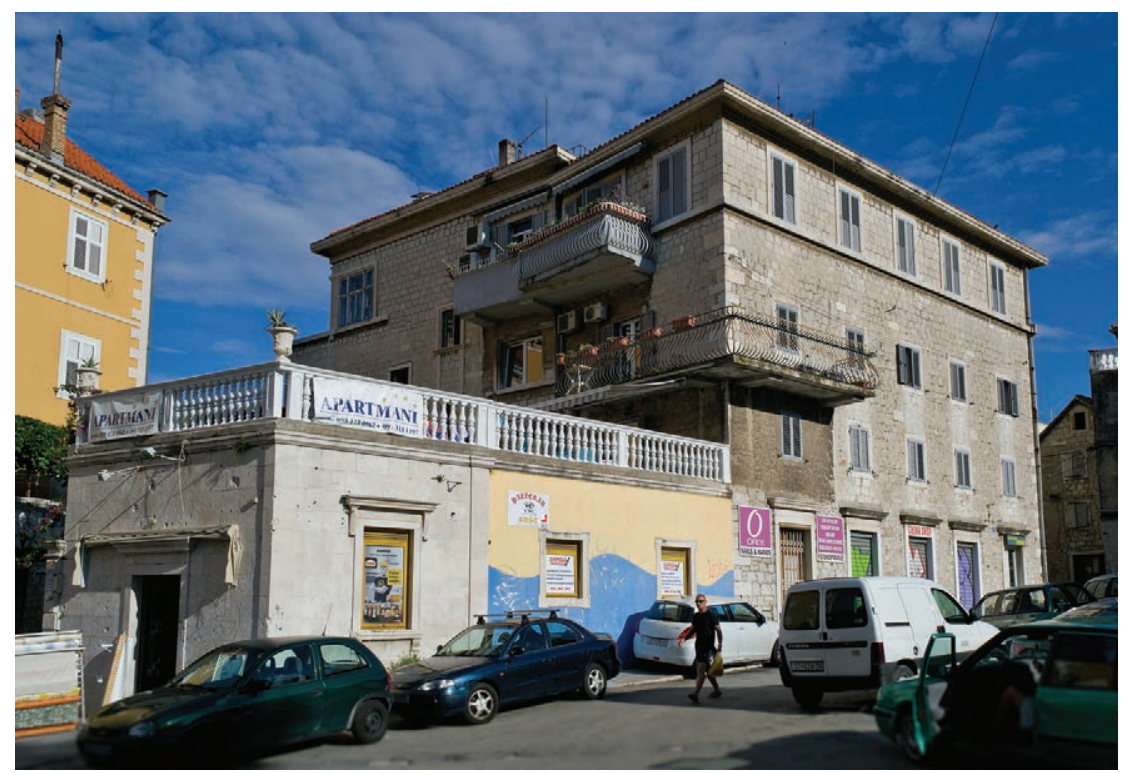

Sl. 2. Sinjska 7

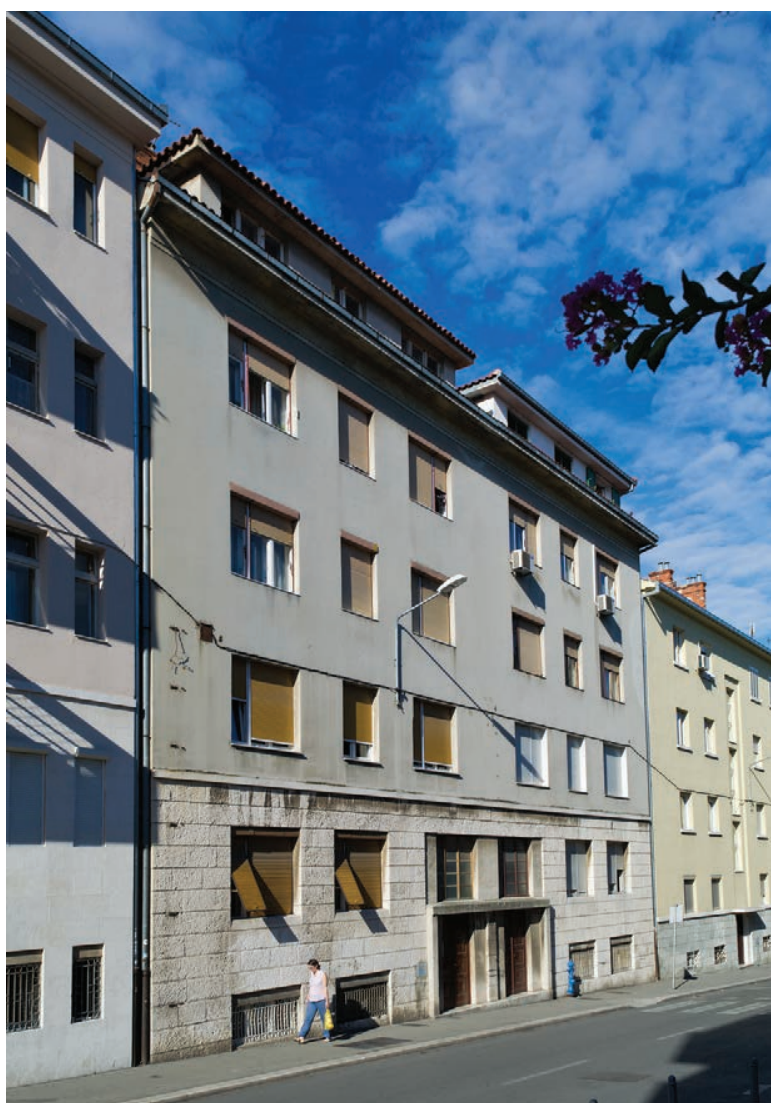

Sl. 3. Bihaćka 5 i Bihaćka 7 


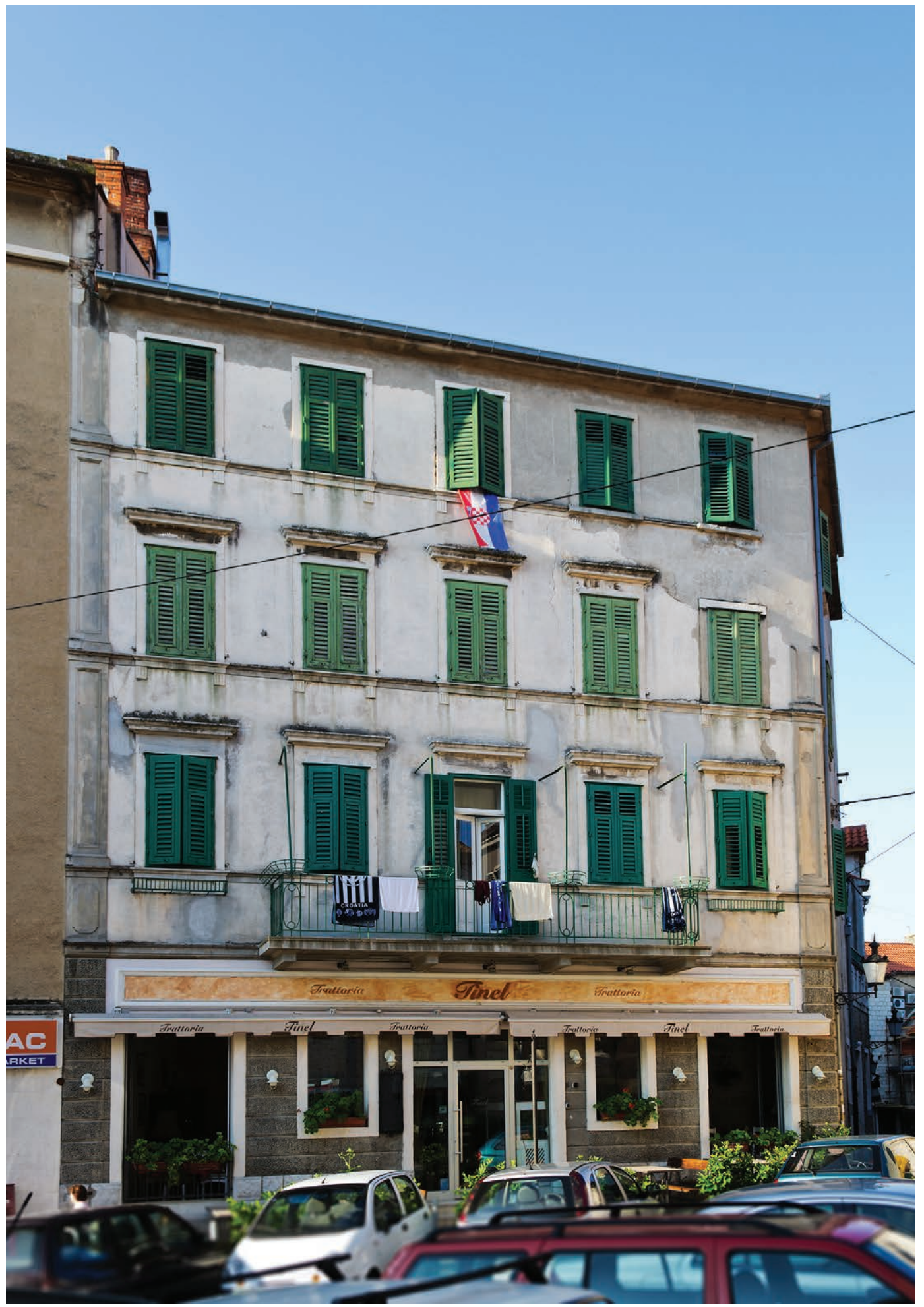




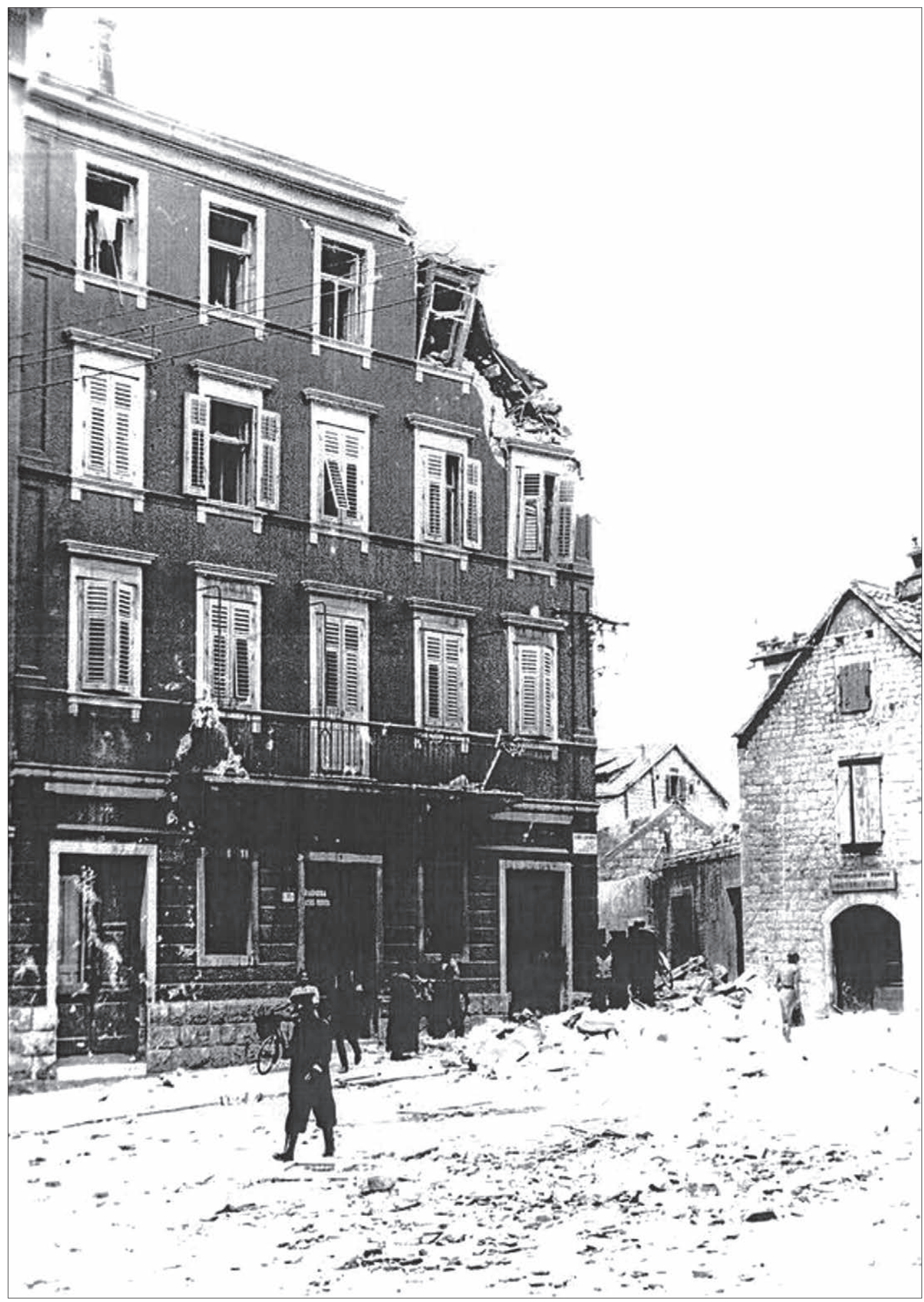

Sl. 5. Tomića stine 1 nakon savezničkog bombardiranja Splita 3. lipnja 1944. 

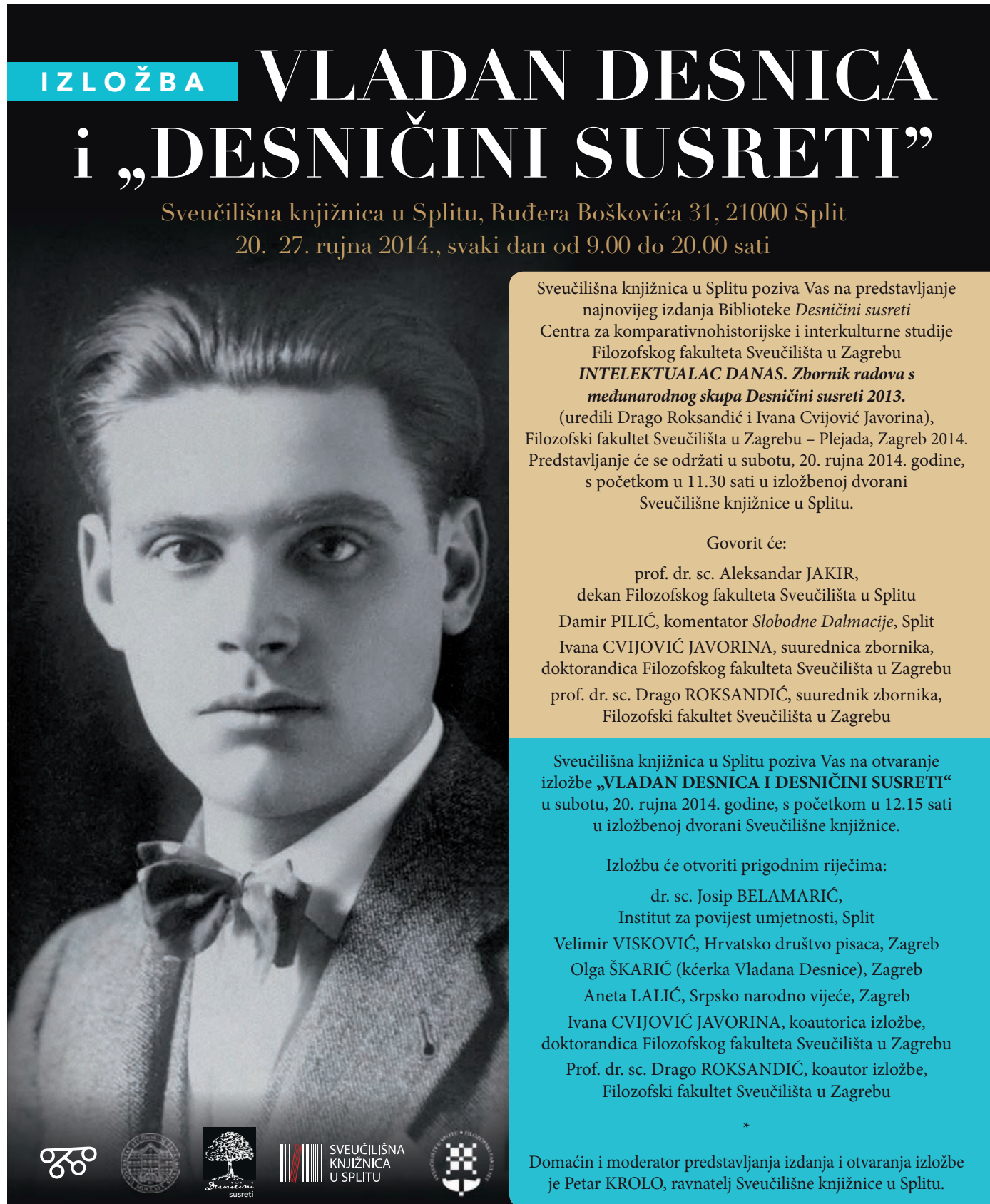

Sveučilišna knjižnica u Splitu poziva Vas na predstavljanje najnovijeg izdanja Biblioteke Desničini susreti Centra za komparativnohistorijske i interkulturne studije Filozofskog fakulteta Sveučilišsta u Zagrebu INTELEKTUALAC DANAS. Zbornik radova s međunarodnog skupa Desničini susreti 2013.

(uredili Drago Roksandić i Ivana Cvijović Javorina),

Filozofski fakultet Sveučilišta u Zagrebu - Plejada, Zagreb 2014. Predstavljanje će se održati u subotu, 20. rujna 2014. godine, s početkom u 11.30 sati u izložbenoj dvorani Sveučilišne knjižnice u Splitu.

Govorit će:

prof. dr. sc. Aleksandar JAKIR,

dekan Filozofskog fakulteta Sveučilišta u Splitu

Damir PILIĆ, komentator Slobodne Dalmacije, Split

Ivana CVIJOVIĆ JAVORINA, suurednica zbornika, doktorandica Filozofskog fakulteta Sveučilišta u Zagrebu prof. dr. sc. Drago ROKSANDIĆ, suurednik zbornika, Filozofski fakultet Sveučilišta u Zagrebu

Sveučilišna knjižnica u Splitu poziva Vas na otvaranje izložbe „VLADAN DESNICA I DESNIČINI SUSRETI“ u subotu, 20. rujna 2014. godine, s početkom u 12.15 sati u izložbenoj dvorani Sveučilišne knjižnice.

Izložbu će otvoriti prigodnim riječima: dr. sc. Josip BELAMARIĆ,

Institut za povijest umjetnosti, Split

Velimir VISKOVIĆ, Hrvatsko društvo pisaca, Zagreb Olga ŠKARIĆ (kćerka Vladana Desnice), Zagreb

Aneta LALIĆ, Srpsko narodno vijeće, Zagreb Ivana CVIJOVIĆ JAVORINA, koautorica izložbe, doktorandica Filozofskog fakulteta Sveučilišta u Zagrebu

Prof. dr. sc. Drago ROKSANDIĆ, koautor izložbe,

Filozofski fakultet Sveučilišta u Zagrebu

Domaćin i moderator predstavljanja izdanja i otvaranja izložbe je Petar KROLO, ravnatelj Sveučilišne knjižnice u Splitu.

Realizaciju izložbe financijski i materijalno su pomogli: Ministarstvo kulture Republike Hrvatske, Savjet za nacionalne manjine Vlade Republike Hrvatske Hrvatsko društvo pisaca (Zagreb), Srpsko kulturno društvo "Prosvjeta" (Zagreb), Društvo za obnovu i revitalizaciju Kule Stojana Jankovića - Mostovi (Zagreb), Srpsko narodno vijeće Zagreb, Centro di ricerche storiche (Rovinj), Muzej grada Splita

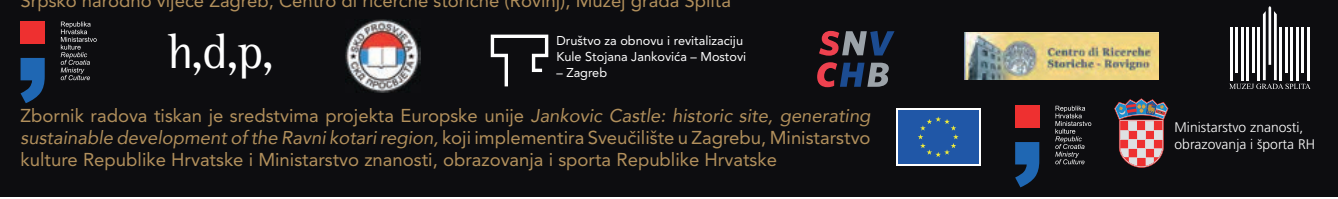

Sl. 6. Plakat izložbe održane u Sveučilišnoj knjižnici u Splitu 20. rujna - 6. listopada 2014. 


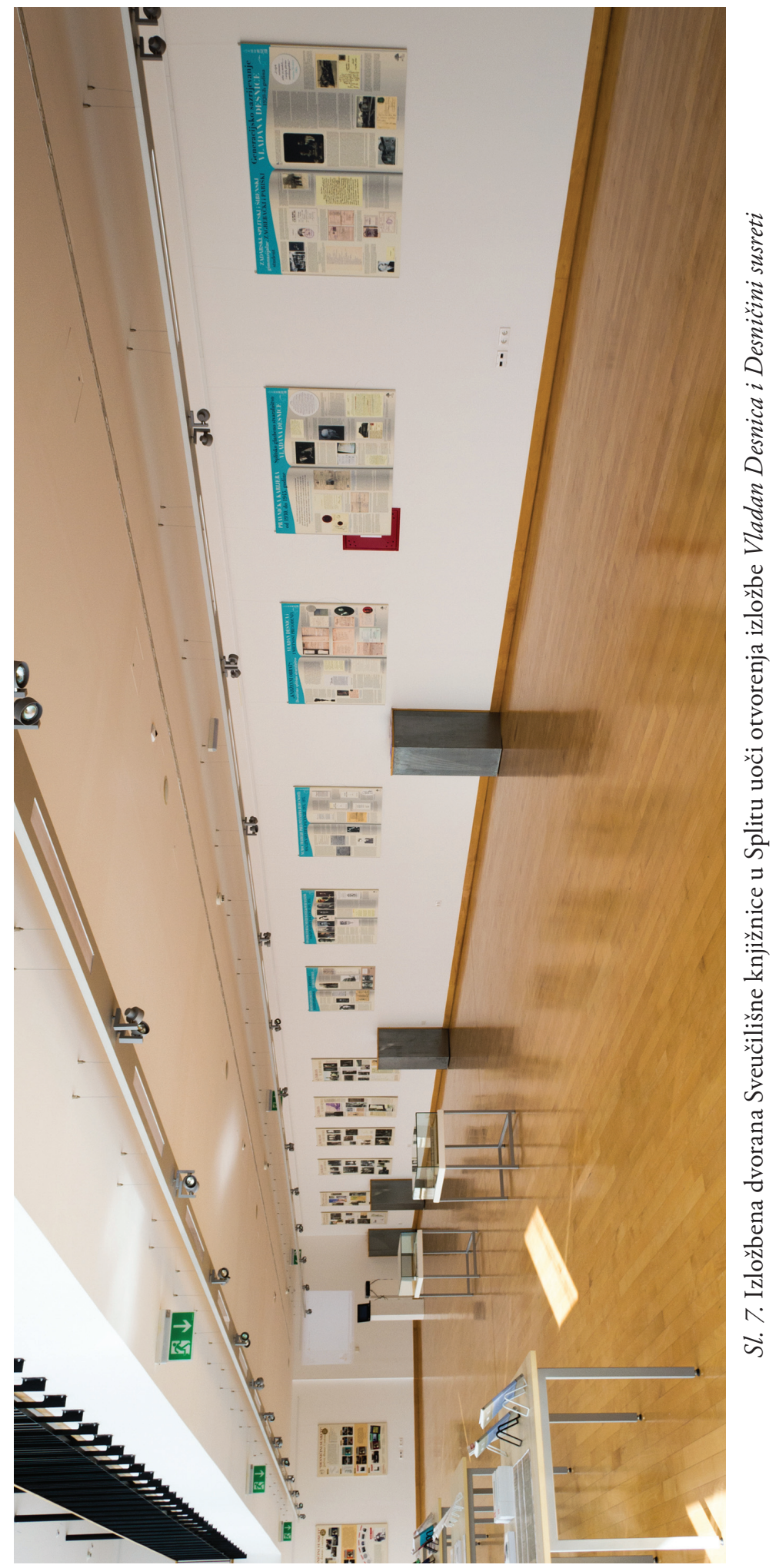




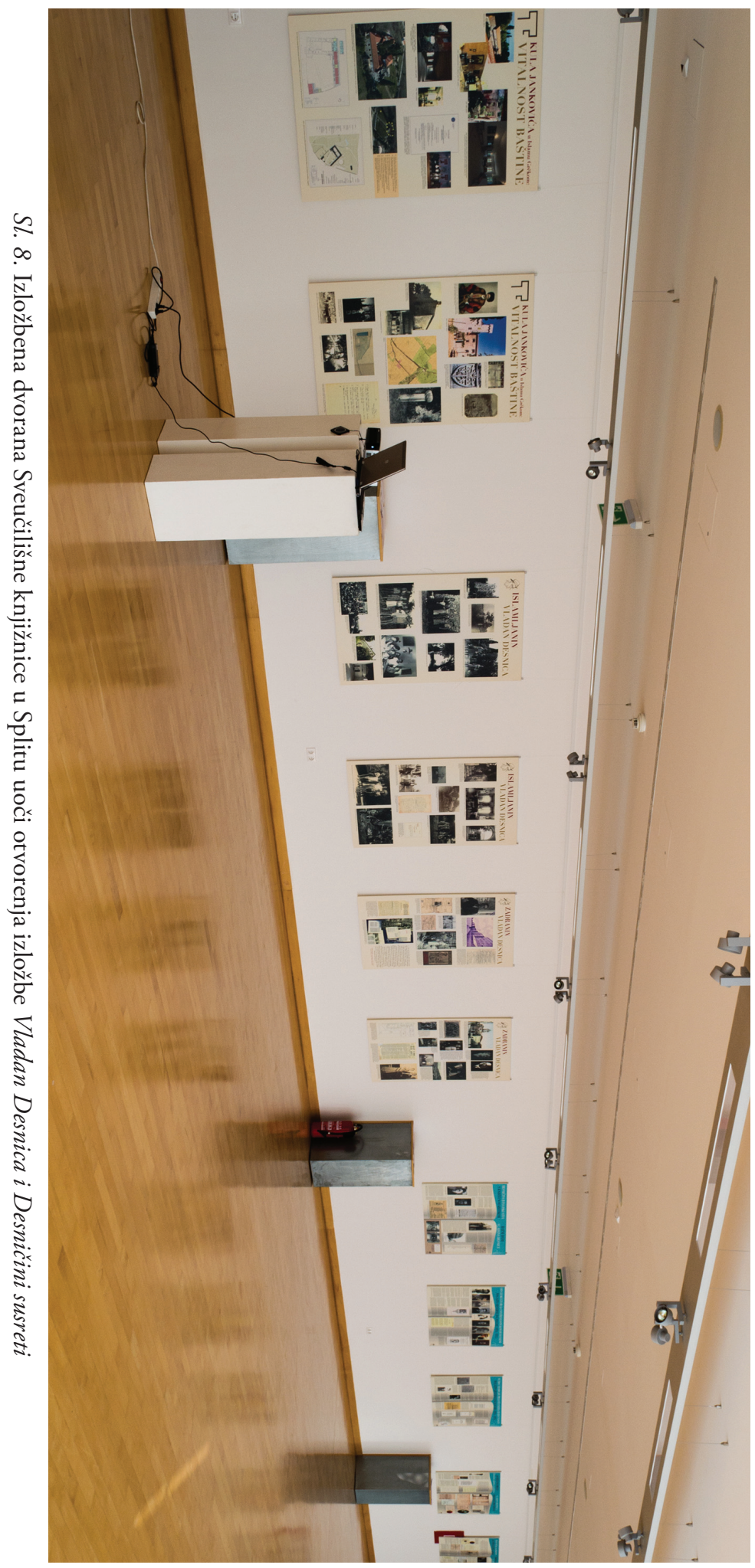




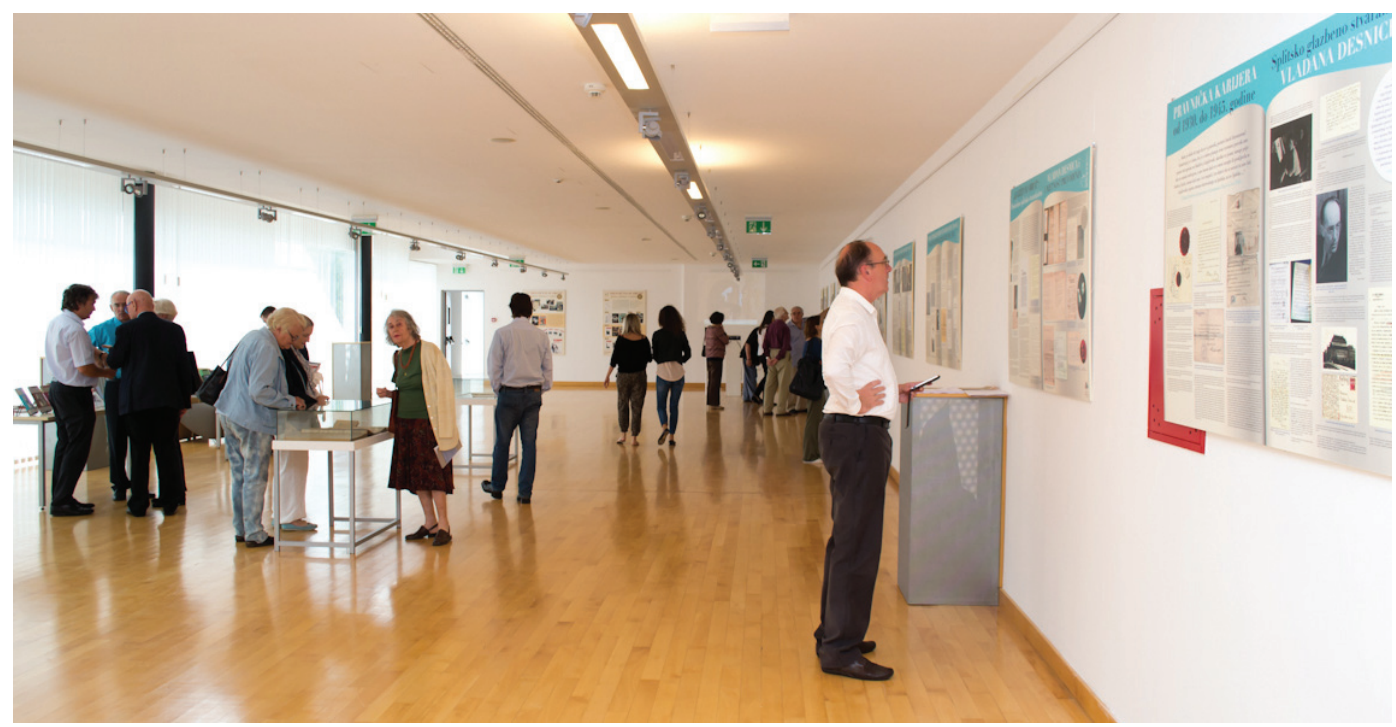

Sl. 9. Posjetitelji razgledaju izložbu Vladan Desnica i Desničini susreti u Sveučilišnoj knjižnici u Splitu 